Meza, Paulina; González-Catalán, Felipe; López-Ferrero, Carmen; Gutiérrez, Israel (2020). "Plain writing in the legal field: An approach from the discourse of specialists" (2020) Discourse Studies, 22(3), 356383, https://doi.org/10.1177/1461445620906027

\title{
Plain writing in the legal field: an approach from the discourse of specialists ${ }^{1}$
}

Abstract. This research aims to describe how practicing lawyers perceive 'plain writing' in the legal field and to conceptualize this notion through the discourse analysis of these specialists. To do so, a qualitative research framed in the interpretive paradigm has been developed. Specifically, 18 practicing lawyers, from different countries and with different specializations in the practicing of Law, were surveyed. After analyzing the discourse of the interviewed lawyers, 8 macro categories accounting for plain language both generally and particularly were identified. The audience was identified as a key element in the production of legal texts which facilitate justice to citizens. Based on our analysis, we conclude with a definition of plain writing.

Keywords: discourse analysis, specialized discourse, written communication, law, legal discourse, plain language, plain writing, access to legal knowledge, legal communicative situation, interpretive paradigm, lawyer interview.

\footnotetext{
${ }^{1}$ This research is part of the FONDECYT Project No. 11170128, entitled "Discursive characterization of genres produced by students of Law and Medicine: their relationship with the perception of selfefficacy in writing, the general quality of the text and disciplinary evaluation".
} 
Meza, Paulina; González-Catalán, Felipe; López-Ferrero, Carmen; Gutiérrez, Israel (2020). "Plain writing in the legal field: An approach from the discourse of specialists" (2020) Discourse Studies, 22(3), 356383, https://doi.org/10.1177/1461445620906027

\section{Introduction}

Producing and understanding specialized texts is a very complex task as it implies mastering a conventionalized discourse, with specific textual and discursive characteristics that depend on factors, such as gender and the environment in which they occur (Gunnarsson, 2009; Gotti, 2011; da Cunha and Montané, 2019). The producers of these texts are experts in their fields; but their addressees sometimes are not. In the legal field, several efforts labelled as "plain language" have been provided to solve the problems that non-expert readers have when trying to understand specialized documents.

Although plain language has gained great interest recently (Castellón, 2009; Songa, 2013; Carretero, 2015; Blank and Osofsky, 2017; Alsina, 2018; among many others), knowledge about its development is dispersed (Schriver, 2017). In addition, plain language and legal writing have seemingly followed independent paths so far. The few studies on legal writing mainly respond to two trends: an approach aiming at a comparison among legal practices in different cultures (Mattila, 2011, 2012), and a characterization of the common discursive genres in this field (Garofalo, 2009; Agüero, 2014; Taranilla, 2015; Aguilar, 2017). Research on plain language, on the other hand, has been focused on delimitating the concept (Mazur, 2000), describing the general panoramas on the subject (Montolío y López Samaniego, 2008; Alsina, 2018) and recommending certain uses (Lauchman, 2008; Montolío and Tascón, 2017; Poder Judicial Chile, 2018). To this division, it should be added that most of the works on plain language come from language specialists, who, usually, fail to know the scope of law or the legal practice in detail. Furthermore, a significant number of proposals is based on normative approaches lacking empirical data, that is, indications on what should be done to write clearly in the legal field. All studies consulted tend to overlook the perception of lawyers for researching plain language and for understanding what "plain language" means for the specialists in the field of law.

Given these gaps, in this investigation we integrate legal writing and plain language with the aim of describing the vision that lawyers have of plain writing in Law. This has allowed us to conceptualize the notion of plain writing in this area and, thus, recognize its key properties. This integration is developed on the basis of an empirical investigation that includes the analysis of descriptions provided by practicing lawyers. To meet our objective, we developed a qualitative research framed in an interpretive paradigm.

Our proposal has the value of being interdisciplinary as includes two experts in language and writing, one expert in education and writing, and a lawyer. In addition, this is an empirical work in which we have collected the contributions of lawyers to understand the construction of legal knowledge and, consequently, their form of written communication. In order to go from legal knowledge to written communication, we have collected perceptions on plain language from lawyers who practice and teach Law so that their assessments can be incorporated to improve the linguistic proposals.

In the theoretical background section, we provide some starting points about plain language, which will allow us to understand, from theory, what is meant by plain language in legal texts. Then, in the results section, after presenting the corresponding methodological aspects, we focus on revealing how the protagonists of the legal acts, i.e. the practicing lawyers, conceive plain language and writing. Finally, we provide some conclusions.

\section{Plain language: Delimitation of the concept}

The plain language movement finds its origin in the proposals promoted by consumer defense organizations in the United States and United Kingdom (Díaz, 2017). This movement seeks to solve the problem of citizens when reading and understanding specialized documents in communicative practices that are realized in stereotyped discursive genres, written in a very formal and specialized register and far from the standard register shared by the average citizen. In this context, it is 
Meza, Paulina; González-Catalán, Felipe; López-Ferrero, Carmen; Gutiérrez, Israel (2020). "Plain writing in the legal field: An approach from the discourse of specialists" (2020) Discourse Studies, 22(3), 356383, https://doi.org/10.1177/1461445620906027

understood that: "a communication is in plain language if its wording, structure, and design are so clear that the intended readers can easily find what they need, understand what they find, and use that information" (International Plain Language Federation: online). From this point of view, a communication with simple language should meet the needs of its audience, when using language, structure and format (design) (Cheek, 2010). The purpose of this movement is, therefore, to ensure that readable texts are written in specialized contexts.

In this line, the concept of readability has to do, above all, with quantitative measures (e.g. punctuation, capital letters, number of words and phrases, etc.) used to calculate text readability; thus, a text with a high readability has short phrases, strong punctuation, short and basic words, concrete nouns, metadiscursive resources, thematic paragraphs, discourse markers, few incidental clauses and low orthographic variation (Cassany, 1995; Sanz and Fraser, 1998). These features, in fact, correspond to those recommended by Montolío (2012b), who, in her proposal for the modernization of legal discourse, suggests, for example, a) to be succinct to prevent citizens from feeling legal prose as strange, outdated, far-fetched and dark; b) to avoid anacoluthons and, therefore, to facilitate the understanding of legal texts; and c) to apply legibility measures, such as short paragraphs and sentences, using periods or full stops (so that reading and comprehension does not become complex, considering that short-term memory does not retain the content read beyond three lines).

In the various proposals developed in relation to plain language, we observe the following assumptions: a) simple and easy texts are regarded as clear (Cassany, 1995); b) the lexicon is one of the linguistic components to be simplified to achieve readability in specialized texts (Etxebarría, 1997), although this point is controversial, since there are works that give greater importance to syntax, when assessing the accessibility to a legal text (Carretero, 2015); c) frequently, the terms language and texts are used as synonyms (Aguirre and Hernández, 1997), blurring any specific variability among the discursive genres involved in the legal fields (e.g., administrative, legal, judicial) (Castellón 2001); and d) the focus is placed on a single reader of legal texts, i.e. the layperson reader (Montolío, 2012b).

As Schriver (2017) concludes, in the last 75 years the studies on plain language have converted from a sentence-based activity focused on readability to a full-text-based activity that has emphasized the principles of writing and visual design. In addition, the concern has been expanded from how people understand the content to whether people rely on it. This development is also present in the Iberoamerican context, where there are multiple advances to modernize and clarify legal language with remarkable initiatives in Spain, Mexico, Argentina, Colombia, and Chile (Arenas, 2018).

\section{Methods}

The objective of this investigation is to describe the notion of plain writing in the field of Law based on the analysis of the discourse of lawyers. This will allow us to approach the concept of plain writing considered by specialists and, thus, identify its core properties. With this purpose, we have developed a qualitative investigation, framed in an interpretive paradigm, which allow us to understand how the interviewed lawyers perceive plain writing. Consequently, the participants' statements have been interpreted so that the value granted by them prevails and, thus, reveals the meaning of what is not evident (Bautista, 2011). Thus, we identify the properties that, from the point of view of lawyers, are associated with the concept of plain writing in the legal field, this is, our research construct.

To collect data, we used an online self-administered questionnaire whose topics emerged from the gaps recognized in previous research on the topic (Díaz, 2017; Gidi and Weihofen, 2018; among others) and the features of the studied construct (Table 1). Thus, the questionnaire was made up of three sections. In the first part, we present four short-answer questions, aimed at collecting personal and academic information from the interviewees (name, institution, degrees and academic degrees, and area of expertise). The second part, consisting of six open-ended questions, aimed to obtain the 
Meza, Paulina; González-Catalán, Felipe; López-Ferrero, Carmen; Gutiérrez, Israel (2020). "Plain writing in the legal field: An approach from the discourse of specialists" (2020) Discourse Studies, 22(3), 356383, https://doi.org/10.1177/1461445620906027

informants' perception of plain language, in general, and plain writing, in particular (see Table 1). In the third part, we included a question to know whether the participants would like to be informed of the results obtained. This questionnaire was created by an interdisciplinary team (a lawyer, a specialist in evaluation and two linguists) and was validated in a triangulation process in which specialists from different areas participated: Law, writing and education. For greater accuracy, Table 1 shows the correspondence between the dimensions of the research construct and the questions comprising the questionnaire:

Table 1. Correspondence between the dimensions of the construct and the questionnaire questions

\section{Construct dimension}

\begin{tabular}{ll}
\hline Definition of plain writing in Law & $\begin{array}{l}\text { 1. What does writing clearly mean in Law? Why should texts be written } \\
\text { clearly in this area? What should texts be written clearly for? }\end{array}$ \\
\hline $\begin{array}{l}\text { Contexts in which plain language } \\
\text { is needed }\end{array}$ & $\begin{array}{l}\text { 2. In which areas of Law do you think the so-called Plain language } \\
\text { movement should be used (between lawyer and client, lawyer and judge, } \\
\text { lawyer and lawyer? (If you need more information about Plain Language, } \\
\text { you can check: https://plainlanguagenetwork.org/plain-language/que-es-el- } \\
\text { lenquaje-claro/) }\end{array}$ \\
\hline $\begin{array}{l}\text { Variation of plain language in the } \\
\text { field of Law }\end{array}$ & $\begin{array}{l}\text { 3. Are there any differences regarding clear writing according to the type of } \\
\text { text produced (sentence, contract, etc.) or the area of law in which a text is } \\
\text { framed (criminal, labor, tax, etc.)? How are these differences incorporated } \\
\text { into plain writing? }\end{array}$ \\
\hline $\begin{array}{l}\text { Linguistic and discursive features } \\
\text { of plain writing }\end{array}$ & $\begin{array}{l}\text { 4. What elements should be considered to write clearly in the field of law? } \\
\text { Why? }\end{array}$ \\
\hline $\begin{array}{l}\text { Compatibility between common } \\
\text { language and legal language }\end{array}$ & $\begin{array}{l}\text { 5. Do you think that writing clearly is compatible with the use of the precise } \\
\text { technical terminology corresponding to Law? }\end{array}$ \\
\hline $\begin{array}{l}\text { Contribution of the Plain Language } 6 . \text { Do you think that the plain language movement is a contribution to the } \\
\text { movement to the legal practice } \\
\text { development and access of legal knowledge? Why? }\end{array}$ \\
\hline
\end{tabular}

\section{Question}

As for data collection, an intentional or non-probabilistic sampling was chosen since the selection of the participants responded to the objectives of the study. Specifically, a casual or incidental sampling was selected since the selection of individuals depended on their availability, that is, we worked with volunteers who agreed to participate on their own initiative (Bisquerra, 2009). Thus, 18 practicing lawyers, all of them Spanish speakers, whose characteristics are specified in Figure 1, were interviewed.

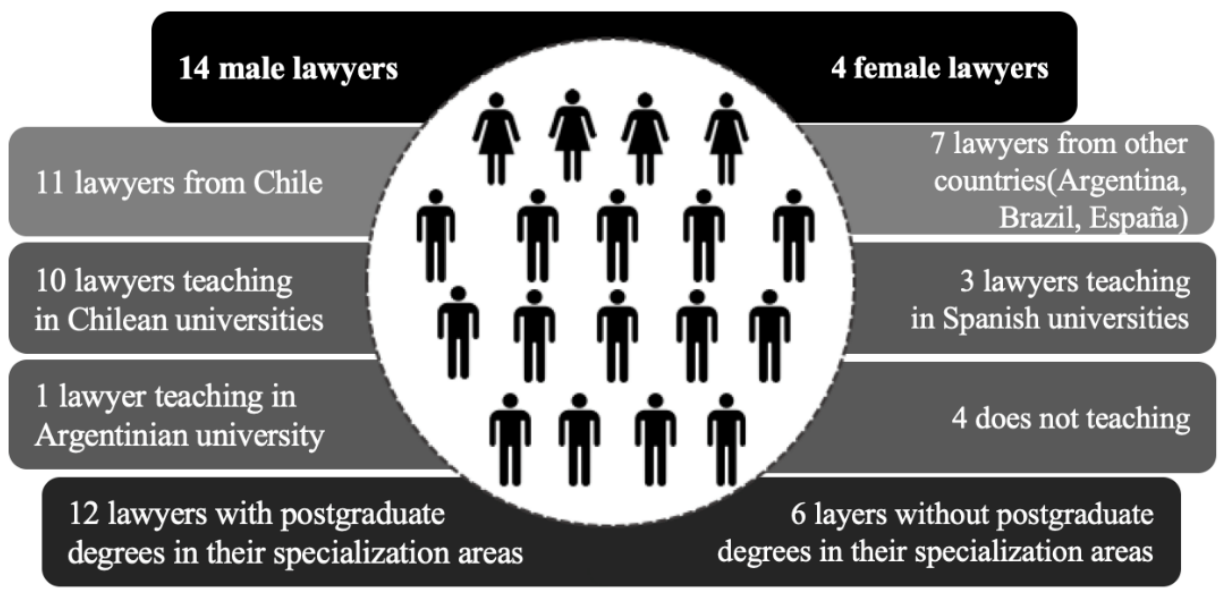

Figure 1. Characteristics of the sample 
Meza, Paulina; González-Catalán, Felipe; López-Ferrero, Carmen; Gutiérrez, Israel (2020). "Plain writing in the legal field: An approach from the discourse of specialists" (2020) Discourse Studies, 22(3), 356383, https://doi.org/10.1177/1461445620906027

The information analysis was carried out manually using content analysis, conceived as the process of interpretation of the collected data through its reduction and categorization (Bautista, 2011). This technique applied to the lawyers' responses allowed us to demonstrate the latent sense of the participants' representations about the phenomenon discussed here. Our objective, systematic and qualitative technique (Krippendorff, 2019) allowed us to formulate exhaustive, reproducible and valid inferences (Porta and Silva, 2003). More specifically, from the analysis of the questionnaires, we proposed a series of categories, corresponding to the properties of plain legal writing, defined by the corresponding disciplinary community. Subsequently, we grouped these categories into 8 macro categories of pragmatic and discursive nature. In Figure 2, we show how this type of analysis was carried out:

In addition, like all scientific-technical discourse, legal discourse - including writing - has a specificity that differentiates it from other discourses and cannot be ignored under penalty of losing its effectiveness and condition. However, as long as categories, concepts and other elements that are proper to the legal discourse are not distorted, it is decisive not to move away from the simplest and most common uses of the language. (Frequentlyy the use of formulas in Latin, French or English, or twists and ritual expressions only leads to an ? (elitist hermeticism, which has nothing to do with the intended scientific character. Then, resorting to a clear) ('anguage, within the framework of its specificity as legal discourse, is a way of ensuring access to rights and (guarantees, and performing more democratic practices of legislating and doing justice.

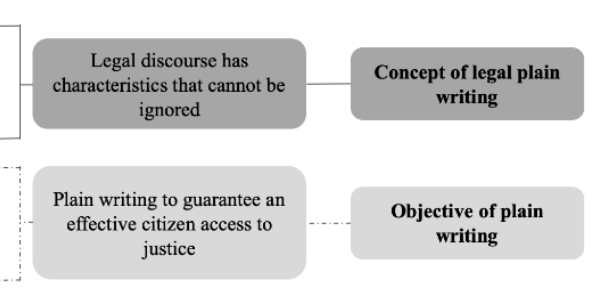

Figure 2. Example of content analysis

Finally, in Figure 3 we synthesize all the methodological procedures described:

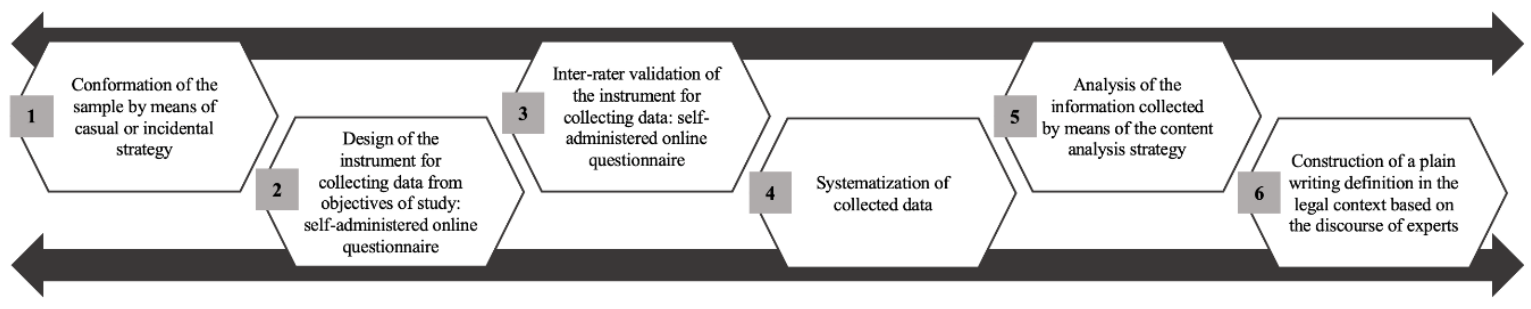

Figure 3. Synthesis of methodological procedures

\section{Results and discussion}

In this section, we present the results obtained from the analysis of the questionnaires applied to lawyers, from which 47 categories related to the concept of plain writing were identified. Each category contains specific information about the aspects involved in plain writing that are of most interest to the legal community. To systematize the information, these categories were organized into 8 macro categories, using a thematic affinity criterion (See Annex 1). The results are presented through a series of charts. For a clearer presentation, the results are provided together with examples that were coded with the number of the question $[P]$ and the participating lawyer $[A]$. Thus, a fragment obtained from question 3 by the lawyer 7 is labeled as [P3, A7]. Chart 1 illustrates the 8 macro categories. 
Meza, Paulina; González-Catalán, Felipe; López-Ferrero, Carmen; Gutiérrez, Israel (2020). "Plain writing in the legal field: An approach from the discourse of specialists" (2020) Discourse Studies, 22(3), 356383, https://doi.org/10.1177/1461445620906027

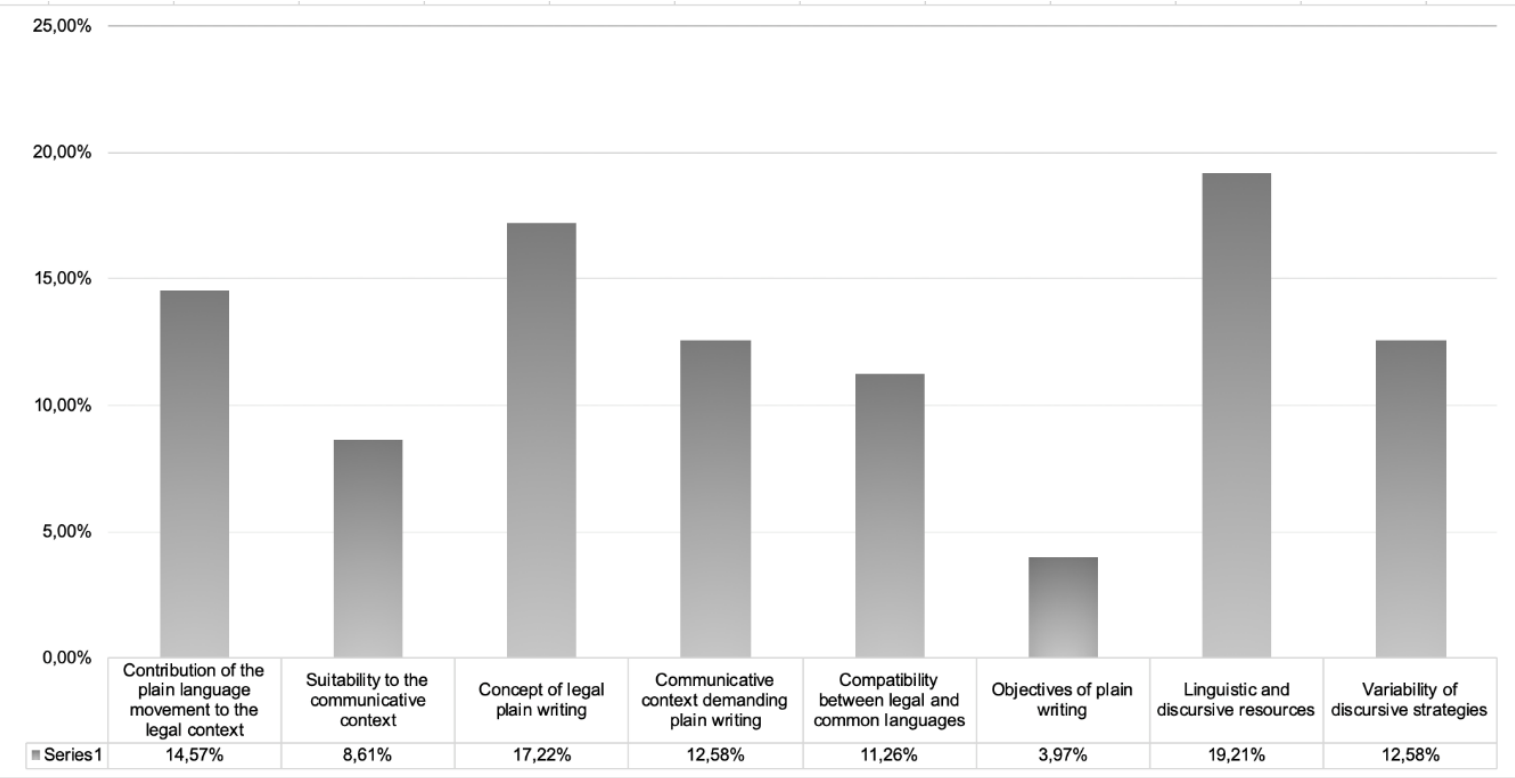

Chart 1. Macro categories identified in the discourse of lawyers referring to plain writing

As shown in Chart 1, 8 macro categories were identified around the subject of plain language, in general, and plain writing, in particular, in the discourse of the participating lawyers. Among them, 5 areas predominate: Linguistic and discursive resources (19.21\%), Concept of plain writing in Law $(17.22 \%)$, Contributions of the plain language movement to the legal field $(14.57 \%)$, Variability of discursive strategies (12.58\%), and Communicative contexts demanding plain writing (12.58\%).

First, the macro category Contributions of the plain language movement to the legal field $(14.57 \%)$ is made up of four specific categories, presented in Chart 2:

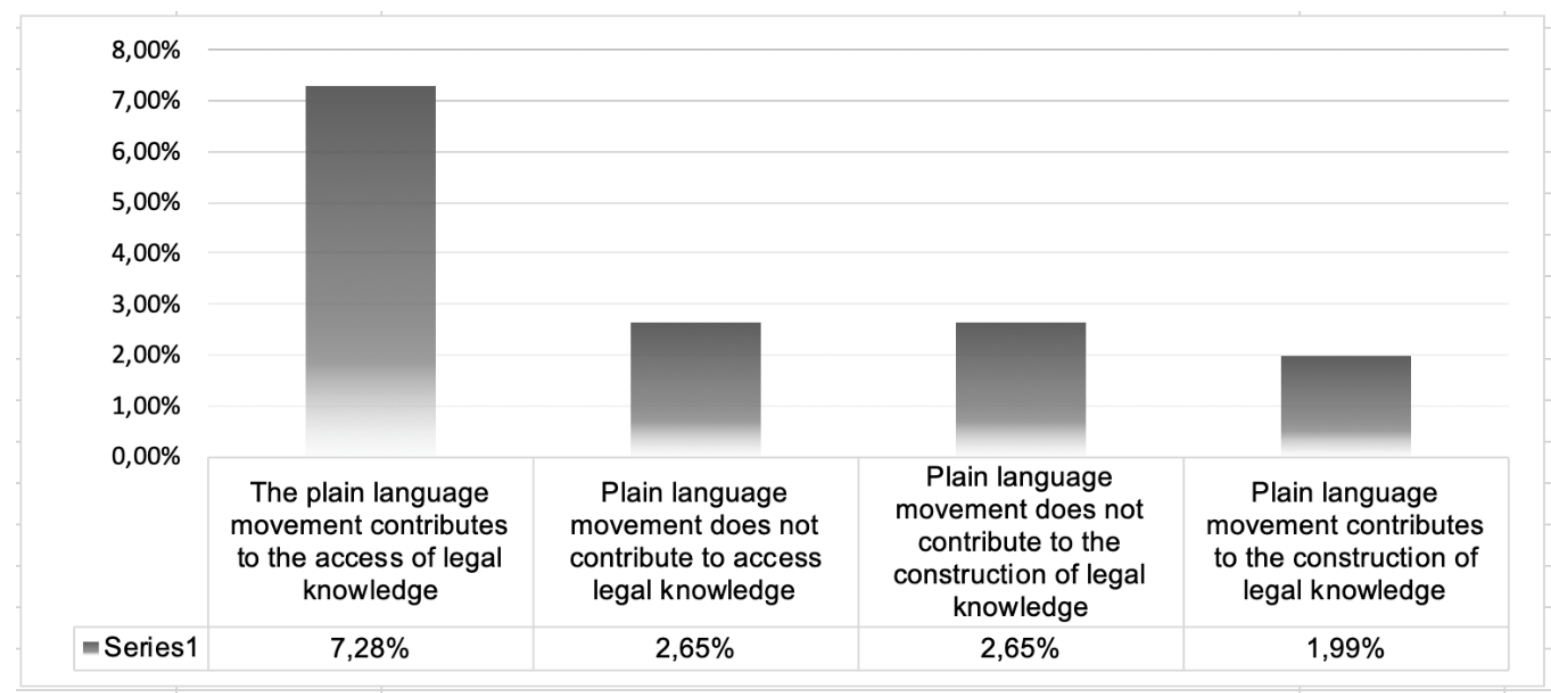

Chart 2. Contributions of the plain language movement to the legal field.

In relation to this macro category, although specialists recognize the contribution of the plain language movement, they admit its value for accessing legal knowledge (7.28\%), but not for constructing it (2.65\%). The following statements illustrate this fact: 
Meza, Paulina; González-Catalán, Felipe; López-Ferrero, Carmen; Gutiérrez, Israel (2020). "Plain writing in the legal field: An approach from the discourse of specialists" (2020) Discourse Studies, 22(3), 356383, https://doi.org/10.1177/1461445620906027

"I do not agree that much with its contribution to the development of legal knowledge, yet I agree with its contribution for accessing knowledge." [P6, A1].

"Specially to access knowledge, to make the legal language kinder and more recognizable". [P6, A5].
Plain language movement does not contribute to the construction of legal knowledge

Plain language movement contribute to the access of legal knowledge

Even more drastically, some interviewees consider the contribution of plain language not only as null but also as an inconvenience, as noted in the following example:

\footnotetext{
"In our area, it has been a problem rather than a contribution. I think it has tended to banalize law, since the legal concepts tend to be forgotten when tried to be explained, aiming only to expand the public that reads it. We must be clear that our public corresponds to legal agents, not people". [P6, A11]
}

Plain language movement does not contribute to the construction of legal knowledge

This last statement is in accordance with the opinion of those academics who have openly rejected the tendency to reduce legal language to common language. Cazorla (2007: 75) points out the special nature of legal language:

Despite much of the social circumstances that prevail today tend to disfigure the legal language with the ultimate intention, unconfessed but latent, of diluting it, mixing it with the common language until losing any identifying feature, and despite the current society favors these extremes, the legal language, to fulfill its mission, must continue to remain a special language with the necessary scaffolding to support its scientific condition.

(our translation)

The reason why specialists consider that the plain language movement only contributes to accessing legal knowledge, but not to constructing it could be because they maintain the thesis that the construction of knowledge in the area should follow the tradition of Law, that is, the use of specialized terminology without simplification. See the following fragment:

\footnotetext{
"The legal writing should not be confused with a simplification in the explanation of a legal institution; this idea of plain language vulgarizes institutions as -among technical peers- it begins to be introduced under the pretext of simplifying language". [P4, A6]
}

For the interviewees, the terminology plays a fundamental role in the management of specialized knowledge, in both production and reception. In this line, text clarity would be conceptually achieved by means of precise vocabulary related to specific legal concepts. In research on legibility, the specific or unknown lexicon is not considered an insurmountable obstacle if it is used appropriately in the structure of the text and in a clear syntactic context that makes reading accessible, such as clarity and order, which are substantial to narration in the legal discourses (Carretero, 2015). Consequently, terminological precision, as a manifestation of the proper use of language, would contribute to readability and thus avoid simplification for the sake of lexical richness.

Here are some examples of the perception that the use of plain language encourages access to knowledge about Law to those who are not specialists in the area: 
Meza, Paulina; González-Catalán, Felipe; López-Ferrero, Carmen; Gutiérrez, Israel (2020). "Plain writing in the legal field: An approach from the discourse of specialists" (2020) Discourse Studies, 22(3), 356383, https://doi.org/10.1177/1461445620906027

"Although I did not know the movement with this name, for some time I have seen different initiatives to bring this technical language closer to the common citizen, which is undoubtedly positive; without going any further, one of the instructions for serving the public where I currently work (Local Prosecutor's Office) is that we should avoid, to the greatest extent possible, using technical terms and try to explain each resolution in a way that each person can fully understand. And I think this is working very well so far". [P6, A16]

Plain language movement contribute to the access of legal knowledge

The concept of citizen accessibility referred to by the specialist above lies in the origins of the plain language movement after the creation of the "Plain English Campaign", whose purpose was to make technical English become more accessible to citizens (Díaz, 2017). This idea of citizen accessibility is acknowledged by some researchers, who claim that clear language is an instrument of democratic construction, regardless of any ideology or government (Cassany, 2005), and that an understandable writing corresponds to a citizen claim as well as to one of the central pillars of public policies (Carretero, 2015).

Access to legal knowledge also appears in the conceptualization of the purposes of plain writing:

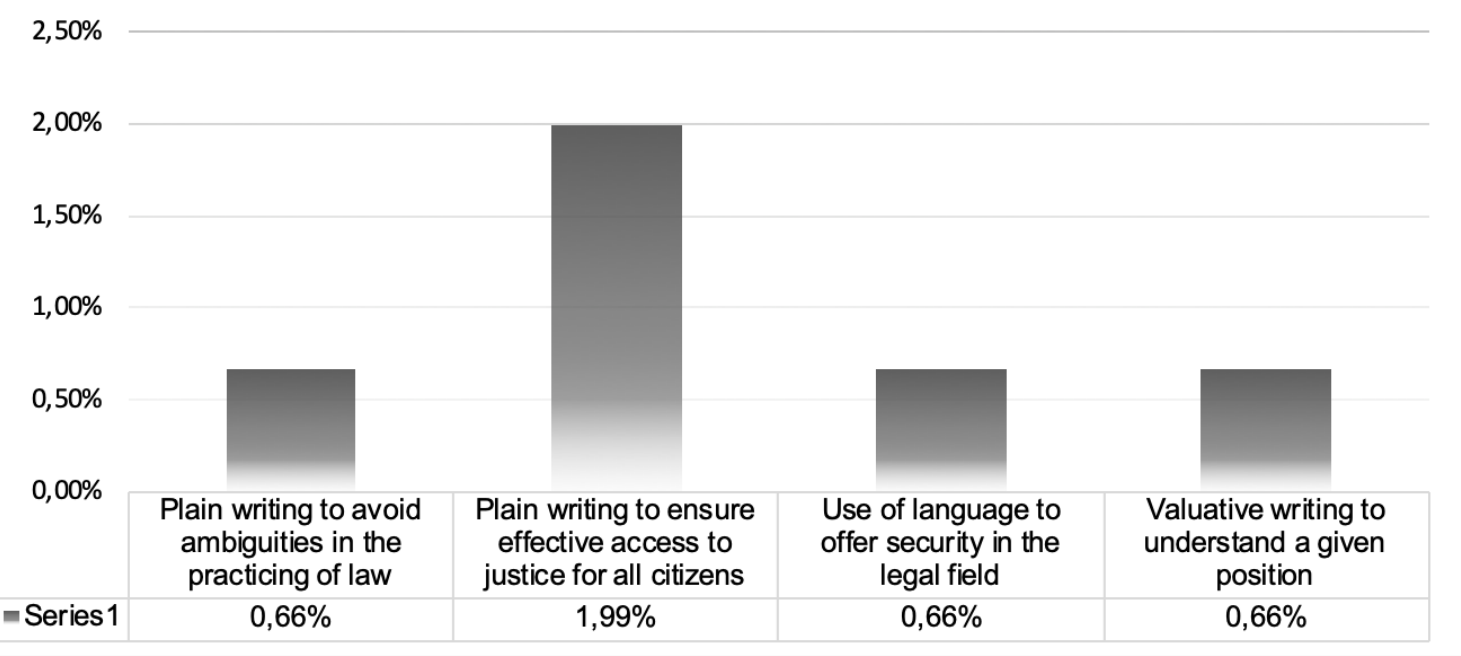

Chart 3. Purpose of plain writing

As can be seen in the chart above, interviewees declare four purposes associated with plain writing. Among them, the one with the greatest presence is the one that attributes to plain writing the purpose of guaranteeing effective access to justice for all citizens (1.99\%). The other purposes declared have an identical presence $(0.66 \%)$ and correspond to three objectives: offer security in the legal field, declare a certain position and avoid ambiguities in the practicing of Law. See the following example:

"Since the rules are manifested through language, plain writing avoids the socalled ambiguities and vagueness of law, and solve them through the interpretive exercise". [P1, A2]

Plain writing to avoid ambiguities in the practicing of law

While the absence of ambiguities is a recurring topic in the information collected about plain writing in this research, the revised literature allowed us to recognize ambiguity as a strategy to develop a good legal writing. For example, Gidi and Weihofen (2018), in their guidelines, consider the strategic use of ambiguity as one of the concrete strategies to achieve quality legal writing. From this, we infer that ambiguity is a strategy used by authors either to provide texts with greater persuasive force, decrease the possibilities of incurring dilemmas or conflicts or to construe texts according to the convenience of the interested party, since, as indicated Hobbs (2011), in case of ambiguity, courts apply interpretive rules or canons of construction. 
Meza, Paulina; González-Catalán, Felipe; López-Ferrero, Carmen; Gutiérrez, Israel (2020). "Plain writing in the legal field: An approach from the discourse of specialists" (2020) Discourse Studies, 22(3), 356383, https://doi.org/10.1177/1461445620906027

As we pointed out, the most prominent purpose of plain writing indicated by the interviewees is to guarantee effective access to justice for all citizens (1.99\%), which is visualized in the following fragment:

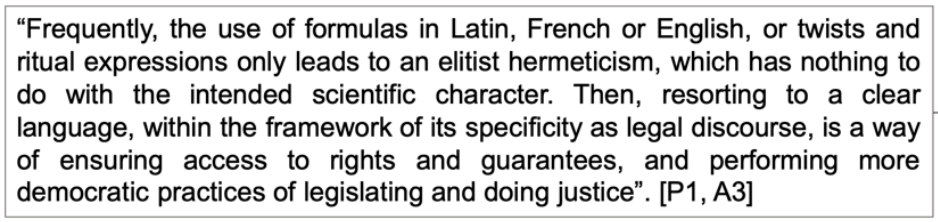

This use of Latin formulas, acknowledged by the lawyer in the example, would be characteristic of the conservatism of the specialized discourse, in general, and of Law, in particular (Gotti, 2011). From our point of view, this devotion to the tradition observed in legal language would be due to the principle of economy of language as well as the marked ritualism of Roman law, whose institutions and teachings have greatly influenced the Western legal systems. In early times, the production of legal consequences was subordinated to the observance of special formulas in order to make oaths, propose designations, write edicts and statutes, issue laws, grant honors or assign properties, among others. In this context, according to Gotti (2011), the formulaic language would be used to guarantee the validity of the action. Following Corral (2018: 194):

it is usual to invoke adages, aphorisms or rules of Law that have been forged with the development of the legal culture and that have a strong relevance as norms that abbreviate a sophisticated reasoning and that are used in legal discourse as topics that have been widely or universally accepted

(our translation)

According to some of the participants in our study, such attributes of legal language would hamper effective access to justice for citizens. Another example for the category in question is:

\footnotetext{
"It should be written clearly since users or readers in the field of law operators are sometimes ordinary citizens who do not have specialized legal training and, therefore, are not familiar with the technical concepts of law, and they wouldn't even have to be. In this way, all law operators, judges, lawyers, academics, officials, among others, can easily communicate with each other and, above all, with citizens". [P1, A18]
}

Plain writing to ensure effective access to justice for all citizens

Following the idea of the example above, we believe that the double solution recommended by González (2009) may facilitate citizen access to justice. The author suggests, on the one hand, the need for legal training as part of the education of citizens, and, on the other, training in legal writing as part of the university curriculum of those who are preparing to practice as judges and lawyers. This recommendation is as follows:

The only way to solve the problems of legal language (to modernize it and bring it closer to the citizen) is by means of a dual training: linguistic training for the lawyer, so that his/her texts are more understandable and elegant; and legal training for the citizen, so that the fundamental concepts are not perceived as strange. While these two aspects are not addressed seriously, we will continue talking about the modernization of the administrative language, but without results or with very partial results (González, 2009: 245).

(our translation)

Thus, in order to guarantee effective access to justice through plain writing, the participating lawyers point out that some fundamental aspects must be taken into account. These aspects are included in the Adaptation to the communicative context dimension: 
Meza, Paulina; González-Catalán, Felipe; López-Ferrero, Carmen; Gutiérrez, Israel (2020). "Plain writing in the legal field: An approach from the discourse of specialists" (2020) Discourse Studies, 22(3), 356383, https://doi.org/10.1177/1461445620906027

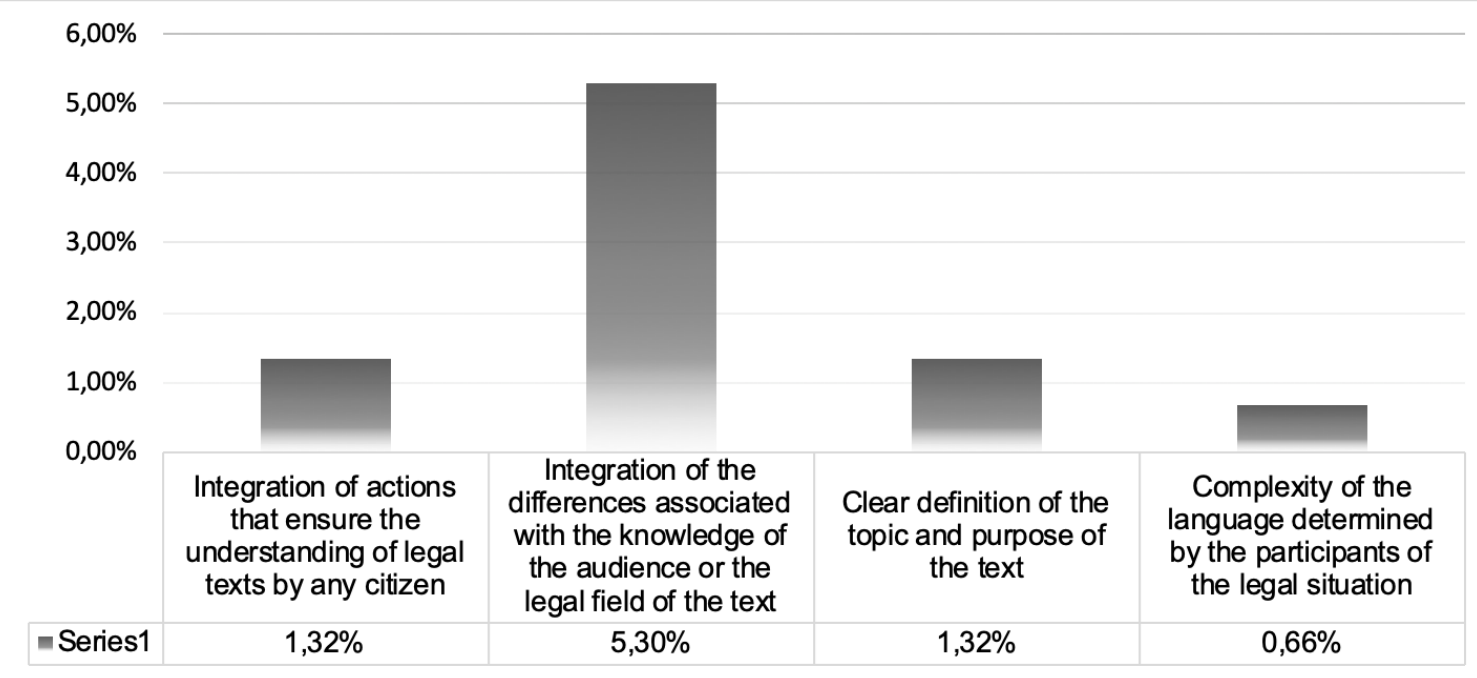

Chart 4. Adaptation to the communicative context

In this dimension, one of the aspects regarding the suitability to the communicative context is related to the need to integrate the differences associated with the knowledge of the audience or the legal field $(5.3 \%)$, which corresponds to the category of greatest presence in the referred dimension. Therefore, for the interviewees, one of the fundamental elements when integrating plain writing in the legal field - which, at the same time, marks a first step in this process - is related to the ability to recognize the characteristics of the audience, identifying, specifically, the level of knowledge about the subject. In this regard, the distinction between a) highly or moderately specialized discourse intended for specialists; b) didactics or learning discourse intended for apprentices; and c) informative discourse intended for the general public is particularly useful in the context of specialized communication (Cabré, 1999). Thus, a terminological selection process can be developed to help addressees understand the message and decide which discursive strategies are most appropriate according to the attributes identified. In this sense, it may be necessary to take into account the identity of the issuer and the addressee of legal texts, i.e. what is expected of them in each communicative situation, what relationship they have, what legal authority they hold.

This idea of considering the characteristics of the audience has been discussed in the context of plain language, in which plain language implies "considering the reader first: discovering what s/he wants to know, what information s/he needs and helping him/her achieve his/her goals. The goal is to make the reader understand a written document the first time s/he reads it" (Plain Language Association International: online). This concern for the audience is also evidenced in the list of recommendations for a good legal writing provided by Gidi and Weihofen (2018). In such list, the authors refer to simplicity, depending on the addressee, stating that jargon should be avoided when writing for people who is not specialized in the area (Gidi and Weihofen, 2018). The suitability for the audience was a central issue in both what has been indicated by our interviewees and the literature on plain language. In this sense, it should be a central dimension in any conceptualization of plain legal writing.

An example of such category is present in the following fragments: 
Meza, Paulina; González-Catalán, Felipe; López-Ferrero, Carmen; Gutiérrez, Israel (2020). "Plain writing in the legal field: An approach from the discourse of specialists" (2020) Discourse Studies, 22(3), 356383, https://doi.org/10.1177/1461445620906027

\begin{abstract}
"The question I permanently ask myself when I write is: who will read this text, will be understood? That involves two aspects: the use of technical terms and expressions that respect our discipline; at the same time, using resources that allow a clear and broader understanding by those who must access it [...] The production of a text implies that the author cannot use clear expressions randomly or categories that are unknown by the reader or are related to other matters". [P4, A12]

"It is evident, from my perspective, that there is no single way to write clearly. Clarity depends on social class conditions, age groups, languages, nationalities, educational levels, historical circumstances, among others. Consequently, it is essential to address these differences. And, in addition, it is essential to differentiate between the areas in which the legal field is diversified, that is, writing in the legal academic field cannot be considered in the same way as in the legislative field. It is necessary to clarify that in a restricted view of law, legal academic discourse of law itself is excluded, which in my opinion is absolutely wrong". [P4, A3]
\end{abstract}

"[To write clearly in the scope of Law] checking out the field of Law and whether the text is addressed to someone with technical knowledge should be both taken into account. Technically it can be clear, but if the person who reads it does not handle such concepts, it turns incomprehensible". $[\mathrm{P} 4, \mathrm{~A} 5]$

\section{Complexity of the language determined by} the participants of the legal situation

As shown in the examples, firstly, both the importance of the audience and the fact that the specialized terminology would vary according to such audience are considered by some lawyers. Secondly, the differences among audiences would be given by different factors (age, language, nationality, social class) that should be considered when writing clearly. Thirdly, other elements, such as the legal field, the field of specialization (professional or academic) and the specific area of Law should also be taken into account.

However, the suitability for the audience flagged by the interviewees is even more complex if we consider, as a general rule, that a double addressee may be involved when writing a discursive genre in the context of Law. For instance, the sentence, which, although is prepared by and for Law specialists, is supposed to have binding effects, generally mandatory, for the parties. From our point of view, the use of plain language in the legal field is not unique, but rather diverse or multiple, so that it meets the needs of all the agents involved and the different communicative situations.

For the respondents, another relevant aspect to fulfil the purposes associated with plain writing in Law is to establish a balance between common and legal languages. Therefore, the suitability of writing to the communicative context will be ensured, as we have already mentioned, recognizing the characteristics of the audience and, consequently, weighting the appropriate use of common and legal languages. This is what the Compatibility between legal and common languages dimension is about: 
Meza, Paulina; González-Catalán, Felipe; López-Ferrero, Carmen; Gutiérrez, Israel (2020). "Plain writing in the legal field: An approach from the discourse of specialists" (2020) Discourse Studies, 22(3), 356383, https://doi.org/10.1177/1461445620906027

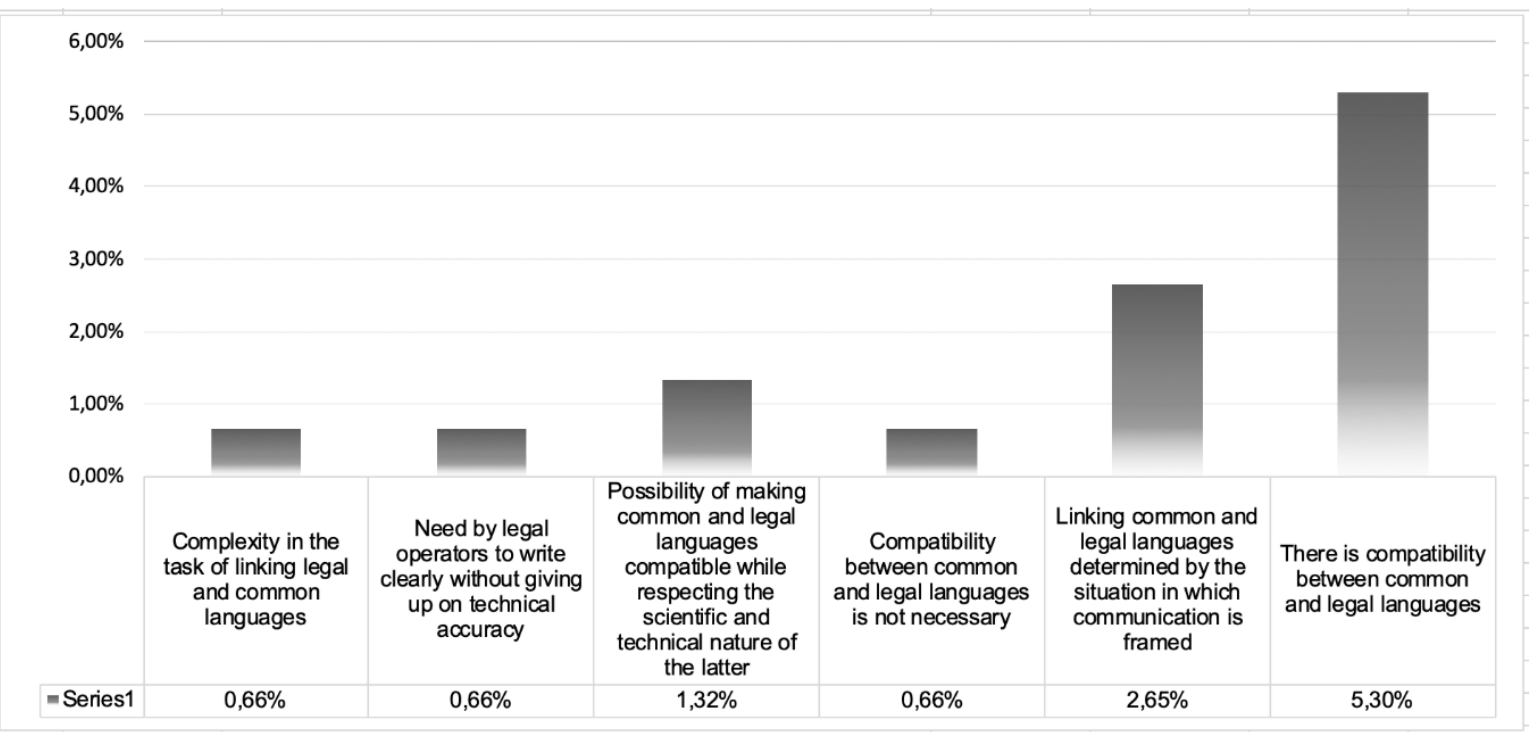

Chart 5. Compatibility between legal and common languages

The category that stands out in such dimension is the one that recognizes the possibility of coexistence between legal and common languages (5.3\%). Here are some examples:

"I certainly believe that [writing clearly using the precise technical terminology corresponding to Law] is possible. Law is expressed through language and it is the duty of legal operators to be able to write clearly, without renouncing to conceptual and technical precision". [P5, A2]

"Writing clearly is a fundamental requirement for a successful practice of law. Unintelligible texts are not admissible on the pretext that the area of Law addressed by such texts is the complex one; a lawyer must "know how to talk" to a judge, a client, a colleague or a stranger with the same clarity". [P5, A14]

\section{There is compatibility between common} and legal languages

Need by legal operators to write clearly without giving up on technical accuracy

As noted in these examples, the idea of considering the audience persists among the interviewees, but, this time, to stress the compatibility between legal and common languages, since lawyers should have the ability to write clearly without sacrificing precision, and to approach audiences with different features. Consequently, informants do not only value that their peers can write clearly for different audiences, but also that they can do it accurately. The value of precision is also mentioned by authors involved in the characterization of legal writing, as they refer to the particularities of the "hostile reader" of legal texts:

the lawyer must write more precisely than almost anyone else. Most writers can expect their work to be read in good faith, with an honest desire to understand what was intended. But the lawyer must write constantly aware of a hostile reader: the party who wants the contract to have contradictions or loopholes; the disappointed heir who wants the will read to defeat the testator's intention; the criminal defendant who wants the statute interpreted so as not to cover a certain act; and all the others who want to twist the meaning of words for their own ends (Gidi y Weihofen, 2018:9).

In this sense, for lawyers, precision would not only be a feature of their writing, but, rather, a fundamental strategy in their professional performance.

However, if both the categories that deny the need for compatibility between legal and common languages and the categories that subordinate such compatibility to certain conditions are considered in conjunction with the categories that highlight a complexity in it, the percentage obtained exceeds 
Meza, Paulina; González-Catalán, Felipe; López-Ferrero, Carmen; Gutiérrez, Israel (2020). "Plain writing in the legal field: An approach from the discourse of specialists" (2020) Discourse Studies, 22(3), 356383, https://doi.org/10.1177/1461445620906027

the category that recognizes the compatibility between legal and common languages $(5.95 \%$ versus $5.3 \%$ ). This shows that the lawyers interviewed are rather reluctant to openly and unconditionally accept the compatibility between legal and common languages, as noted in the following statements:

\begin{tabular}{l}
$\begin{array}{l}\text { "It is compatible to the extent that the specificity of the legal discourse is } \\
\text { respected. To assimilate the clear writing in the legal field with a "common" } \\
\text { writing, of generalized use, would be to ignore its scientific and technical } \\
\text { character". [P5, A5] }\end{array}$ \\
\begin{tabular}{|l|}
\hline "More than compatibility, I see no need". [P5, A6] \\
languages compatible while respecting the \\
scientific and technical nature of the latter
\end{tabular} \\
\begin{tabular}{|l|l|}
\hline "It is an arduous task, since many terminologies of law are used in \\
common language with other meanings, often opposite". [P5, A1]
\end{tabular} \\
\hline
\end{tabular}

This compatibility between legal and common languages will be determined, according to the interviewees, by the characteristics of the context in which the process of legal communication takes place. In this regard, specialists mention that there will be areas in which it will be more necessary to use plain writing. Chart 6 shows the elements identified around the Communicative contexts demanding plain writing dimension:

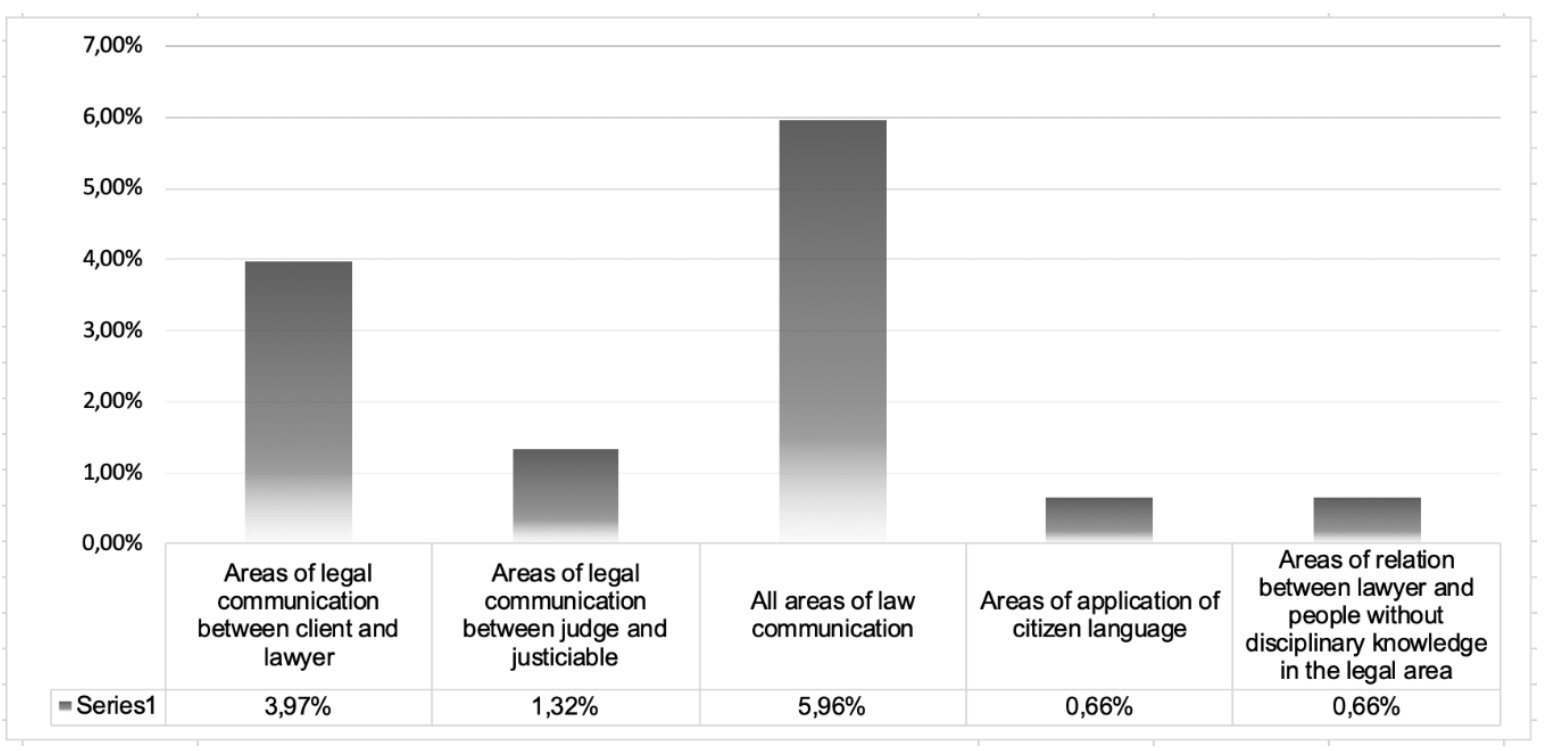

Chart 6. Communicative contexts demanding plain writing

As can be observed, the longest bar represents the idea that plain writing is a tool that should be applied in all communicative contexts of legal nature (5.96\%). Here there are some examples:

"I believe that it should be used in all the afore mentioned fields because, as I indicated earlier, it is essential that the members of society achieve an adequate understanding of the legal contents so that their behavior can be expected or adequate from a legal point of view. In addition, understanding the content of the legal norm is essential even for the recipient of a sanction to understand its meaning, that is, know why it is being sanctioned by the State. Regarding the need for clarity, it is important to note that clarity in the use of language does not exclude the use of the technical terms of each science, on the contrary, it imposes its correct and timely use". [P5, A1] 
Meza, Paulina; González-Catalán, Felipe; López-Ferrero, Carmen; Gutiérrez, Israel (2020). "Plain writing in the legal field: An approach from the discourse of specialists" (2020) Discourse Studies, 22(3), 356383, https://doi.org/10.1177/1461445620906027

"Any communication, at any level, must always be clear. For different
reasons, as in the case of the lawyer-client relationship, in which the latter
is not familiar with the legal language (and doesn't need to be), it is
necessary to pave his/her way to ensure his/her right to understand the
situation in which s/he is and to make the corresponding decisions. But
also, among technicians (lawyer-judge and lawyer-lawyer) clarity, which is
never in contradiction with knowledge, is needed. Personally, I distrust the
lack of clarity, precisely because it reveals poor attention to the
understanding of the message that, in all these cases, is essential for a
correct relationship between professionals or, at a contractual level, with
the client". [P2, A12]

These examples reinforce the statements of lawyers who claim that the various legal texts should be understandable to those who will be reached by their consequences. Therefore, for them, plain writing should be used in all legal communicative fields, an idea shared by the supporters of plain language (Cheek, 2010; Barranca, 2017). However, if we consider all the categories that indicate that the application of plain writing should be restricted only to specific areas $(6.61 \%)$, such addition exceeds the idea that puts forward the transversal application of plain writing to any communicative context. Examples accounting for these restrictions are:

"Lawyer-Client, and I would add Judge-justiciable". [P2, A1] Areas of legal communication between judge and justiciable

"Only between client and lawyer". [P2, A6]

Areas of legal communication between client and lawyer

"I know the principle of the plain language movement, but in our area, I think it should be applied only based on the concept of citizen language. That is applicable to the client-attorney and citizens-lawyer relationship. It is not possible for the relationship lawyer/lawyer or judge/lawyer, since there the words have a rather technical character. If a lawyer cannot use and understand technical language, it means that he/she is poorly trained. That is why I do not believe in a legal training with a citizenship approach; rather, it is to learn a language with new words than different logical evidences". [P2, A11]

"I think the most fertile ground is the client-lawyer relationship. In a sentence, the judge cannot sacrifice technical (complex) language for the sake of easy understanding. If in this movement [plain language] clear means easy, I think it is the wrong way". [P2, A17]

The majority of the respondents restrict the application of plain writing to certain areas, particularly the lawyer-client relationship, due presumably to their asymmetry regarding the knowledge of technical information and the need for the client to understand the practical scope of his/her legal situation. In accordance with this idea, Coloma and Agüero (2012) suggest that lawyers should be able to communicate with other colleagues, professionals from other disciplines and lay people as well as to address legal problems with clients moderating his/her linguistic uses so that his or her interlocutor can fully understand. In this sense, according to these authors, in certain contexts a good lawyer is like a good translator, an idea that underlies what our respondents have affirmed.

Applying plain writing to certain communicative contexts of a legal nature will imply that specific linguistic-discursive features are considered and integrated in the text production process. These features will allow the message to be clearly transmitted to the different participants in the communicative situation. In this line, according to our respondents, the linguistic and discursive elements that should be considered when writing a clear text in the legal field are: Use of precise legal technical language (6.62\%), Application of grammar rules in the production of texts $(2.65 \%)$, Explanations using simple language (2.65\%), and Use of the legal technical language (2.65\%). These features can be seen in Chart 7: 
Meza, Paulina; González-Catalán, Felipe; López-Ferrero, Carmen; Gutiérrez, Israel (2020). "Plain writing in the legal field: An approach from the discourse of specialists" (2020) Discourse Studies, 22(3), 356383, https://doi.org/10.1177/1461445620906027

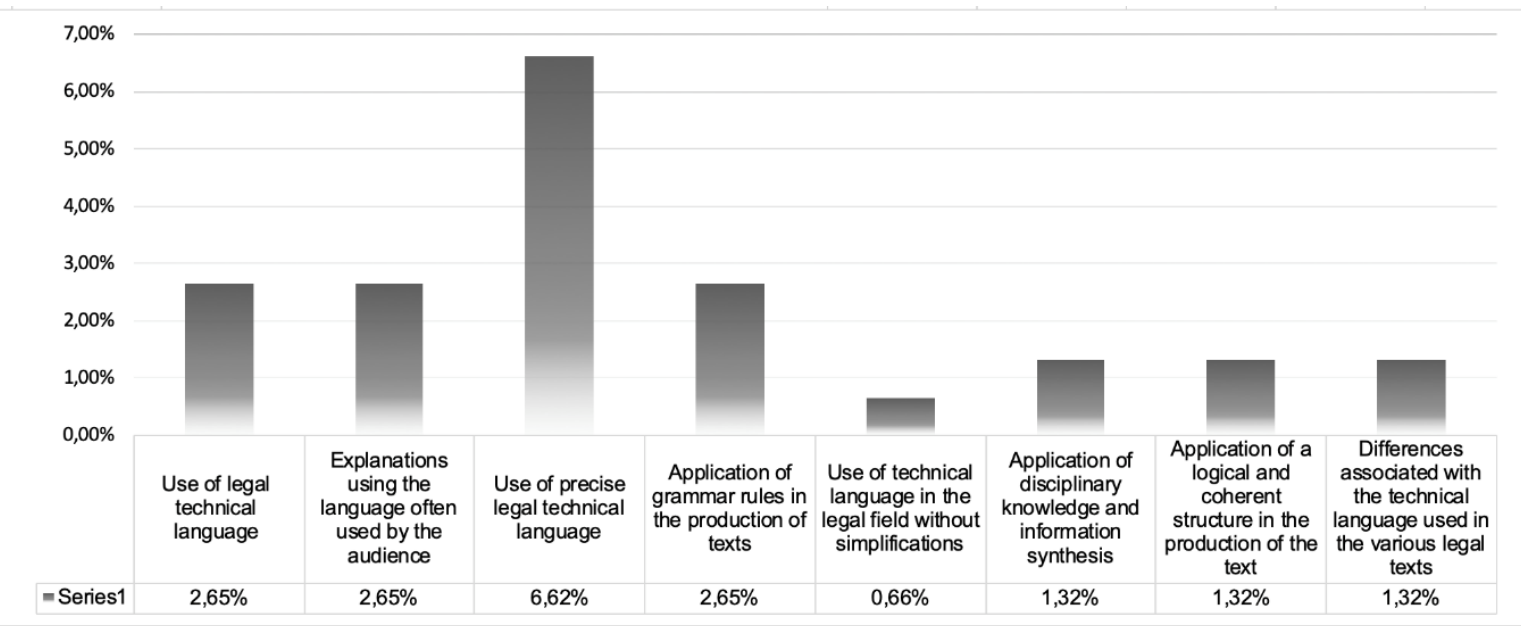

Chart 7. Linguistic and discursive features

As noted in the chart, when addressing the issue of linguistic and discursive features of plain legal writing, the category most referred to by specialists is the Use of precise legal language $(6.62 \%)$. This is consistent with the idea previously discussed that the construction of knowledge in Law should maintain the tradition of the field, this is, respecting specialized scientific knowledge and technical terminology, with no need for simplification. Likewise, it is consistent with the result that shows that most of the specialists do not recognize a total compatibility between legal and common languages nor endorse the idea of a transversal application of plain writing in any communicative context.

In addition, this result suggests an important concern among the interviewees for maintaining the specialized discursive characteristics of their discipline by using specific linguistic-discursive features. Thus, the use of precise legal technical language would make it possible to comply with the precision and mono-referentiality of the specialized discourse, in which "every term must point immediately to its own concept", and "every term signals a concept and effectively condenses the semantic value contributed by the defining process which generated it" (Gotti, 2011: 25). Then, from our point of view, the use of precise terminology, which should not be at odds with clarity, would strengthen the accuracy that must necessarily prevail in legal texts.

In this sense, the use of specialized terms might be justified by the principle of economy of language, because of the high degree of precision and conciseness, which avoids or diminishes the multiple interpretations and their consequences. In the same vein, it has been affirmed that, in Law, the possibility that the introduction of new terms will lead to ambiguity favors the presence of traditional linguistic features, which are preserved even when they vanish from general language. Thus, old formulas would be preferred to newly coined words due to their centennial history and their highly codified and universal interpretations (Gotti, 2011).

The following fragments illustrate the concern for technical terminology as a central linguisticdiscursive feature of a plain legal writing: 
Meza, Paulina; González-Catalán, Felipe; López-Ferrero, Carmen; Gutiérrez, Israel (2020). "Plain writing in the legal field: An approach from the discourse of specialists" (2020) Discourse Studies, 22(3), 356383, https://doi.org/10.1177/1461445620906027

"[The clear language movement is not a contribution] because it is misused by vulgarizing technical terminology. In other areas of science, particularly in the exact sciences, nobody questions the chasm between technical language and the understanding of the passive subject of the communicational relationship, for example: doctor-patient relationship". $[\mathrm{P} 6, \mathrm{~A} 6]$

The different co-occurrences of these linguistic-discursive features are manifested in the variability of discursive strategies recognized by the specialists. This information has been systematized in Chart 8:

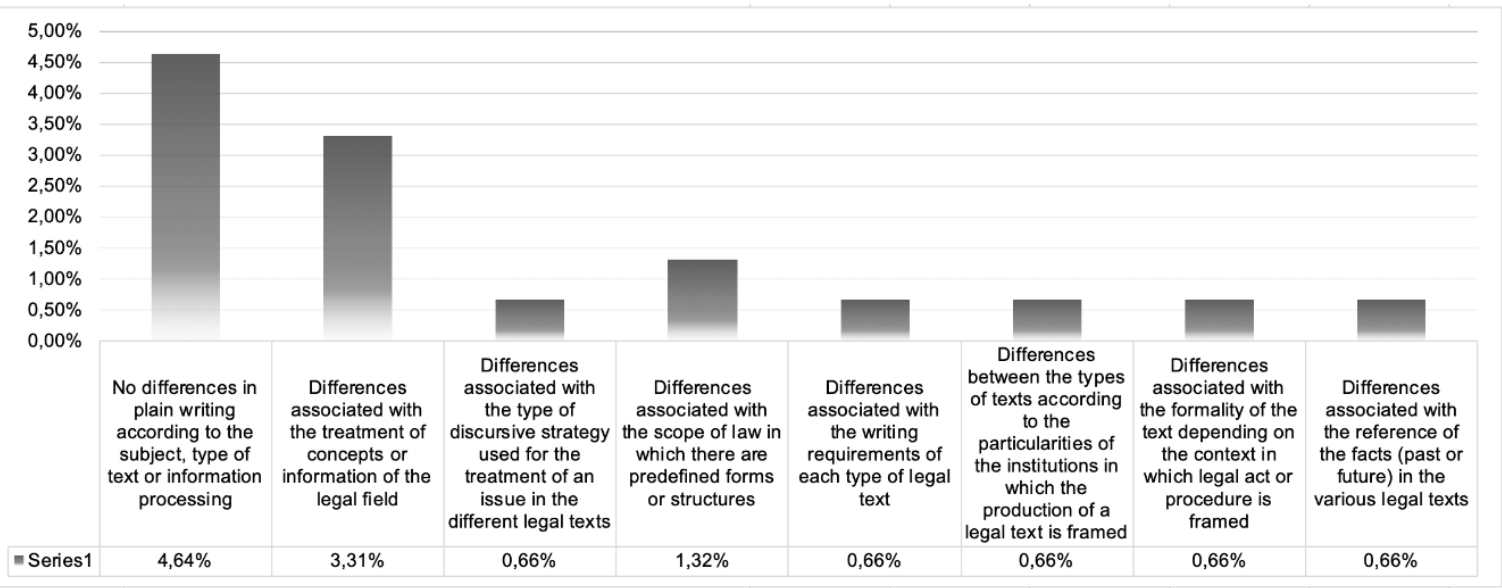

Chart 8. Variability of discursive strategies

The longest bar in the chart indicates that there are no differences in plain writing according to the topic, type of text or information processing (4.64\%). See an example in the following fragment:

"There's no difference. A good criminal legal text, for example, should be understood by a lawyer independently of the area in which s/he specializes. They all share the same structure that makes them accessible to the other legal operators". [P3, A11]
No differences in plain writing according to the subject, type of text or information processing

However, as in previous cases, if we add up the remaining bars, which indicate that there are differences in the areas in which plain writing is needed, the result far exceeds the claims denying differences (7.93\%). Specifically, the lawyers interviewed recognize distinctions associated with factors such as: treatment of concepts or information specific to the legal field (3.31\%), treatment of an issue in different genres $(0.66 \%)$, the scope of law $(1.32 \%)$, the form of writing in the texts associated with different discourse genres $(0.66 \%)$, the particularities of the institutions $(0.66 \%)$, the context of the legal act or procedure $(0.66 \%)$, and the reference of the facts $(0.66 \%)$. This variability in the legal plain writing is illustrated in the following examples:

"Indeed, there are differences in plain writing according to the type of text and the area in question. In general terms, in the scope of the contractual process and practice, a high degree of ritualism is verified, which is manifested in the mechanical use of certain expressions and forms of writing. In turn, depending on the area of Law, it is possible to identify technicalities and diverse structures that, beyond the disciplinary depth, often repeat classic or historical formulas, which do not necessarily aim to Differences between the types of texts according to the particularities of the institutions in which the production of a give greater clarity to the legal language". [P3, A2] 
Meza, Paulina; González-Catalán, Felipe; López-Ferrero, Carmen; Gutiérrez, Israel (2020). "Plain writing in the legal field: An approach from the discourse of specialists" (2020) Discourse Studies, 22(3), 356383, https://doi.org/10.1177/1461445620906027

"The wording is different depending on the legal text (lawsuit, sentence, contract, etc.) and also changes depending on the area of law (civil concepts differ from criminal ones for example). One must adapt the writing and concepts as indicated". [P3, A5]

"Yes, there are. In Criminal Law, clarity is especially important since legal certainty is more necessary. The same in Tax Law, since economic sanctions are usually common. For this reason, it is about preventing the wording of rules from being ambiguous or vague". [P3, A9]
Differences associated with the scope of law in which there are predefined forms or structures

"Totally. Specially, in relation to the procedural areas of law, in which there are greater difficulties in separating ourselves from technical terminology, especially in civil and criminal proceedings, in which words used in the lego language are synonyms, such as prisoner and inmate, for example, they both have precise and profoundly different meanings in technical language. In other areas of law, that is, of substantive law, this difference is not as marked and I believe that there is much more space to advance in clear language, especially in areas such as family law, which has important components of reality more than technical issues". [P3, A16]

Differences associated with the scope of law in which there are predefined forms or structures

Based on these results, the criteria for plain language, in general, and plain writing, in particular, should be presented in a more concrete way, i.e. by classes of texts or genres of discourse, instead of a decontextualized and abstract form. With these results, we can affirm that, for the interviewees, the concept of plain writing is not unique but subject to the aforementioned variations. Consequently, the attributes of a plain legal text will be determined by the legal communicative situation, which will be instantiated in the discursive genres as pragmatic and communicative units, so that this discursive variation will also reflect the linguistic variation and the discursive strategies used.

Finally, the last chart functions as a type of synthesis of the concept of plain legal writing from the point of view of the specialists interviewed.

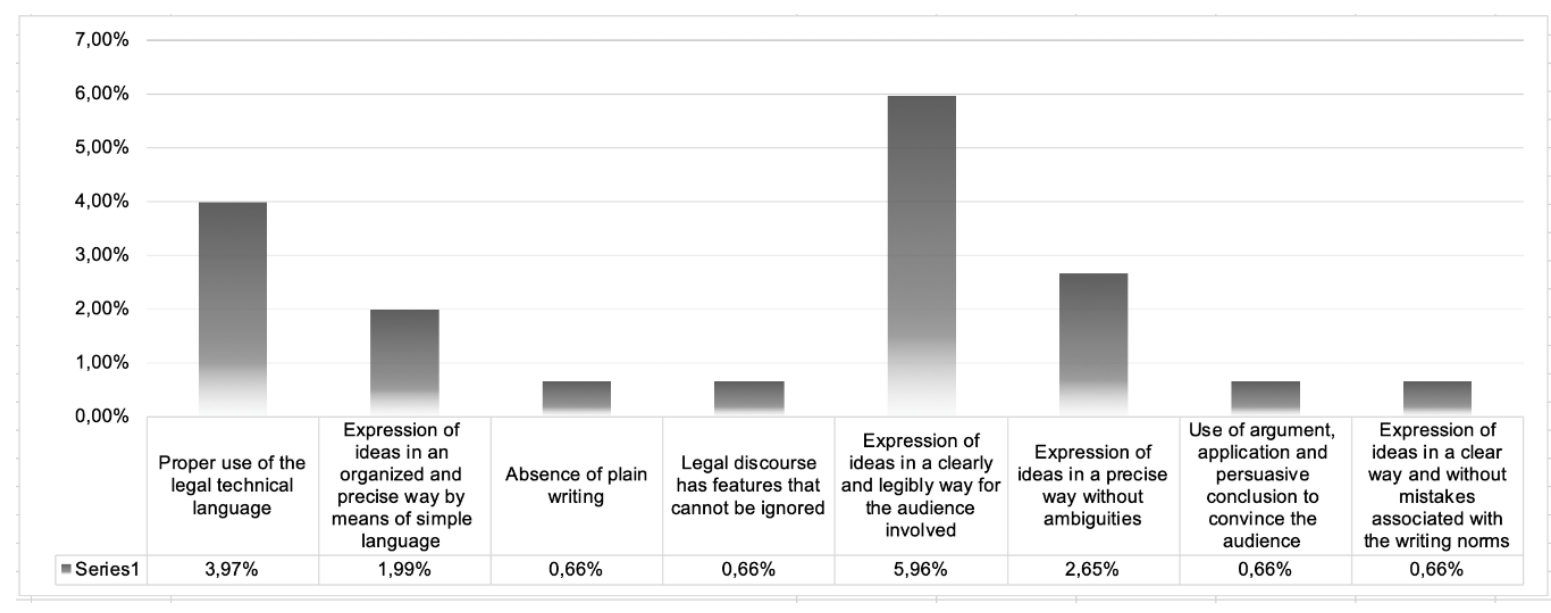

Chart 9. Plain writing concept

As noted, among the interviewed lawyers, the prevailing perception is that plain legal writing is related to the expression of ideas in a clear and understandable way for the audience involved $(5.96 \%)$. See the next example: 
Meza, Paulina; González-Catalán, Felipe; López-Ferrero, Carmen; Gutiérrez, Israel (2020). "Plain writing in the legal field: An approach from the discourse of specialists" (2020) Discourse Studies, 22(3), 356383, https://doi.org/10.1177/1461445620906027

\footnotetext{
"Writing clearly in law involves, in my view, two aspects: in the first one, it means that the message should address the receiver clearly, without interference, avoiding misunderstandings; and the second aspect of our discipline, writing clearly in law means using legal institutions in a relevant way, that is, burglary cannot be identified with theft, for example. As for the second question, law is like a scalpel that must make the incision in the right place to identify and solve the problem at the lowest possible cost". [P1, A8]
}

Clear and understandable expression of ideas for the audience involved

Other frequent elements referred to in this dimension, already mentioned above, were the correct use of technical language, the use of simple language, and the omission of ambiguities. The grammatical and normative aspects were also regarded as relevant characteristics of plain writing. Thus, the use of technical language [P1, A1], the absence of spelling, grammar and writing mistakes [P1, A18] were emphasized. These ideas are synthesized in the following fragment:

"It means transmitting knowledge, ideas, concepts and resolutions grammatically correct and without deliberately using terms that can lead to error or confusion, so that the recipient or recipients of the writings know without any doubt the meaning of the writing, and the consequences that may be derived from it in relation, in particular, to the rights and obligations that correspond to it". [P1, A10]

Clear expression of ideas without errors associated with writing rules

This idea of complying with the writing conventions is interesting since, in general, it was not present in the literature, for example, on legal writing style (Alcaraz, Hugues and Gómez, 2014; Gidi and Weihofen, 2018) or legal discourse modernization (Montolío, 2012 a, b). This absence could be due to the fact that good spelling, punctuation or compliance with grammatical norms are basic aspects of any type of writing, not only of specialized writing, so mentioning them might be considered unnecessary in specialized manuscripts on legal discourse. In any case, if the practicing lawyers highlighted these aspects related to plain writing, then such aspects would not be as obvious or frequent as one would expect.

\section{Conclusions}

In order to achieve our research objectives, based on our analysis we can identify some central features of plain writing in the legal field according to the perception of the lawyers interviewed. Thus, plain writing in Law would aim to guarantee effective access to justice for all citizens, avoid ambiguities, offer security in the legal field and evidence a position. Some characteristics of this type of writing are a) proper use of the legal technical language; b) expression of ideas in an organized and precise way by means of simple language and without ambiguity; c) use of argument, application and persuasive conclusion to convince the addressee; d) absence of errors associated with the writing norms; e) application of grammar rules; and f) logical and coherent textual structure. To make the message understandable to all, interviewees claim that a clear definition of the topic and purpose of the text, as well as of the legal area, must be considered. In this way, the complexity of the language used may be determined by these variables.

While our characterization provides invaluable information on how plain writing is conceived by practicing lawyers, some aspects may be open to debate. Firstly, regarding the objectives of plain writing, the fact that it guarantees access to justice for all citizens is questionable since it exceeds the limits of plain writing. Instead, we believe that the purpose of this type of writing is to ensure the intelligibility of the different legal institutions to the greatest extend possible, given their effects in the context of life in society. Secondly, we question argumentative elements as attributes of plain writing because the argumentative nature is restrictive only to some legal texts. Thus, plain legal writing cannot be subject to this characteristic.

On the basis of the characterization and discussion presented, we offer a definition of plain writing in the legal field. We understand plain writing in Law as the process of constructing legal discourses aimed at promoting the intelligibility of the various legal institutions or institutions of Law, such as 
Meza, Paulina; González-Catalán, Felipe; López-Ferrero, Carmen; Gutiérrez, Israel (2020). "Plain writing in the legal field: An approach from the discourse of specialists" (2020) Discourse Studies, 22(3), 356383, https://doi.org/10.1177/1461445620906027

sentences, regulations, contracts, etc., in order to offer or strengthen security in the legal field. From the general to the particular, the features of this type of writing are: a logical and coherent textual structure; the expression of ideas in an organized way through simple language or frequently used language; precision, that is, the absence of ambiguities and the use of precise technical terminology in the legal field; the use of correct and legible grammar structures; and the absence of errors associated with the writing norms. As for the message, it should be understandable to all participants of the legal communicative situation, an achievement that is subordinate to both a clear definition of the subject and its purpose and to the considerations of the legal field.

As a synthesis, the following figure illustrates the elements comprising the definition of plain writing:

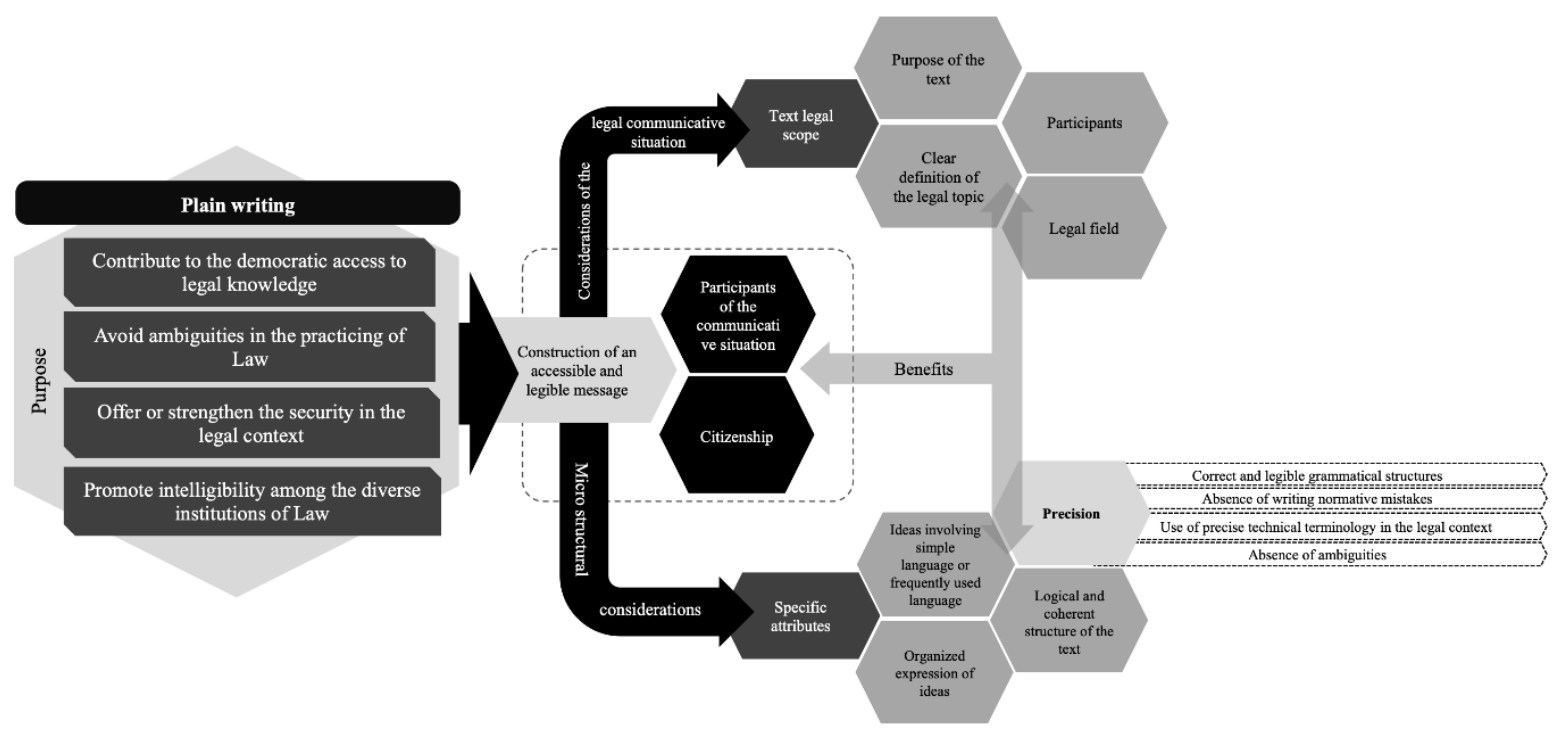

Figure 4: Synthesis of the plain writing definition

Our definition includes a broad spectrum of elements ranging from those of a global type, such as textual structure, to those of a local type, such as terminology and grammar. From our point of view, both the definition and the figure of synthesis above can be a contribution to work with plain writing in Law. For example, characterization of the attributes could be guiding criteria for assessing plain writing in the legal field. The conceptualization of the notion of plain writing from a pragmatic and communicative perspective, based on the discourse of specialists, may be a contribution as well. Our proposal differs from previous research in which plain writing, in particular, has not been defined (only plain language in general, Mazur, 2000). It also differs from normative guidelines lacking substantial empirical investigation that involves specialists referring to the central elements of plain language in general (Carretero, 2015; Poder Judicial Chile, 2018) or the legal style in particular (Alcaraz, Hugues and Gómez, 2014; Muñoz, 2017; Gidi and Weihofen, 2018). Thus, on the basis of our proposal, we offer clear writing guidelines that take into account the linguistic and disciplinary specificity as they consider the perception of the Law specialists themselves.

As the rise of the of this movement in Hispanic countries has occurred is recent, an interesting projection of the present research would be to contrast our results with the data collected from novice lawyers. We believe that these participants would show a more open and favorable attitude towards plain language movement than the experienced lawyers, as the ones who participated in our research. 
Meza, Paulina; González-Catalán, Felipe; López-Ferrero, Carmen; Gutiérrez, Israel (2020). "Plain writing in the legal field: An approach from the discourse of specialists" (2020) Discourse Studies, 22(3), 356383, https://doi.org/10.1177/1461445620906027

\section{References}

Agüero C (2014) ¿Conforman las sentencias penales un género discursivo? Estudios Filológicos 53: 7-26.

Aguilar P (2017) Una propuesta de géneros discursivos escritos del ámbito universitario, jurídico y chileno, orientada a la alfabetización académica de estudiantes de Derecho. Perfiles Educativos 39(155): 179-192.

Aguirre B and Hernández C (1997) Lenguaje jurídico. El español por profesiones. Madrid: Sociedad General Española de Librería.

Alcaraz E, Hughes B and Gómez A (2014) El español jurídico. Barcelona: Ariel.

Alsina A (2018) Endeavours towards a plain legal language: The case of Spanish in context. International Journal of Legal Discourse 3(2): 235-268.

Arenas G (2018) Lenguaje claro (derecho a comprender el Derecho). Eunomía. Revista en Cultura de la Legalidad 15: 249-261.

Bautista N (2011) Proceso de la investigación cualitativa. Epistemología, metodología y aplicaciones. Bogotá: Editorial El Manual Moderno.

Barranca M (2017) El proceso de modernización del lenguaje jurídico en el Reino Unido, los Estados Unidos y España, y su reflejo en el lenguaje utilizado por los jueces, FITISPos International Journal: Public Service Interpreting and Translation 4: 85-101.

Bisquerra R (2009) Metodología de la investigación educativa. Madrid: La Muralla.

Blank J and Osofsky L (2017) Simplexity: Plain Language and the Tax Law. Emory Law Journal 66: 189-263.

Cabré M (1999) La terminología: Representación y comunicación. Una teoría de base comunicativa y otros artículos. Barcelona: Institut Universitari de Lingüística Aplicada. Universitat Pompeu Fabra.

Carretero C (2015) La claridad y el orden en la narración del discurso jurídico. Revista de LLengua $i$ Dret 64: 64-85

Cassany D (1995) La cocina de la escritura. Barcelona: Anagrama.

Cassany D (2005) Plain language in Spain. Clarity. Journal of the International Association Promoting Plain Legal Language 53(1): 41-44.

Castellón H (2001) El Lenguaje administrativo: formas y usos. Granada: La Vela.

Castellón H (2009) Hacia la claridad en los textos administrativos. Revista de Llengua i Dret 52: 85115.

Cazorla L (2007) El lenguaje jurídico actual. Pamplona: Aranzadi.

Cheek (2010) Defining Plain Language. Clarity 64: 5-15.

Coloma R and Agüero C (2012) Los abogados y las palabras: una propuesta para fortalecer competencias iniciales en los estudiantes de Derecho. Revista de Derecho 19(1): 39-69.

Corral H (2018) Curso de Derecho Civil. Parte General. Santiago de Chile: Thomson Reuters.

Da Cunha I and Montané M (2019) Textual genres and writing difficulties in specialized domains. Revista Signos. Estudios de Lingüística 52(99): 4-30.

Díaz S (2017) Luces y Sombras del lenguaje jurídico para la ciudadanía. Tesis de Grado, Universidad del País Vasco, España.

Etxebarría M (1997) El lenguaje jurídico-administrativo: propuestas para su modernización y normalización. Revista Española de Lingüística 27(2):341-380. 
Meza, Paulina; González-Catalán, Felipe; López-Ferrero, Carmen; Gutiérrez, Israel (2020). "Plain writing in the legal field: An approach from the discourse of specialists" (2020) Discourse Studies, 22(3), 356383, https://doi.org/10.1177/1461445620906027

Garofalo G (2009) Géneros discursivos de la justicia penal. Un análisis contrastivo español- italiano orientado a la traducción. Milán: Franco Angelini.

Gidi A and Weihofen H (2018) Legal Writing Style. St. Paul: West Academic Publishing.

González J (2009) El lenguaje jurídico del siglo XXI. THEMIS 57-Revista de Derecho 57:235-245.

Gotti M (2011) Investigating Specialized Discourse. Bern: Peter Lang.

Gunnarsson B (2009) Professional Discourse. London: Continuum International Publishing Group.

Hobbs P (2011) Defining the law: (Mis)using the dictionary to decide cases. Discourse Studies 13(3):327-347

International Plain Language Federation (2019) What is Plain Language? Available at: https://plainlanguagenetwork.org/plain-language/what-is-plain-language/ (accessed 22 June 2019).

Krippendorff K (2019) Content analysis an introduction to its Methodology. London: Sage.

Lauchman (2008) A Handbook for writers in the U.S Federal Government. Rockville: Lauchman Group.

Mattila H (2011) Cross-references in Court Decisions: A Study in Comparative Legal Linguistics. Lapland Law Review 1:96-121.

Mattila H (2012) Jurilinguistique comparée: langage du droit, latin et langues modernes. Québec: Yvon Blais.

Mazur B (2000) Revisiting plain language. Technical communication 47(2): 205-211.

Montolío E and López Samaniego A (2008) La escritura en el quehacer judicial. Estado de la cuestión y presentación de la propuesta aplicada en la Escuela Judicial de España. Revista Signos 41(66): 33-64.

Montolío E (2012a) La modernización del discurso jurídico español impulsada por el Ministerio de Justicia. Presentación y principales aportaciones del informe sobre el lenguaje escrito. Revista de Llengua i Dret 57: 95-121.

Montolío E (2012b) Hacia la modernización del discurso jurídico. Barcelona: Edicions Universitat de Barcelona.

Montolío E and Tascón M (2017) El Derecho a entender: Comunicación Clara. Available at: https://www.prodigiosovolcan.com/pv/comunicacion/assets/ComunicacionClara.pdf (accessed 25 January 2019).

Muñoz S (2017) Libro de estilo de la Justicia. Barcelona: Espasa.

Plain Language Association International (2019) ¿Qué es el Lenguaje Claro? Available at: https://www.prodigiosovolcan.com/pv/comunicacion/assets/ComunicacionClara.pdf (accessed 25 January 2019).

Poder Judicial Chile (2018) Informe de reporte de actividades Comisión de Lenguaje Claro. Available at:

http://ipj10-

110.poderjudicial.cl/documents/10179/10264695/8.17.+Comisi\%C3\%B3n+de+Lenguaje+Claro.pdf/ a152a82b-9da0-4d33-ad98-072c6a5a8770?fbclid=IwAR0pChV5K0IwAzfOONxz2pWE0X SEpPdi2ritiZ BSmlxZGx6ov8ffFiZw (accessed 30 June 2019).

Porta L and Silva M (2003) La investigación cualitativa: el análisis de contenido en la investigación educativa. Anuario digital de investigación 14: 1-18.

Sanz G and Fraser A (1998) Manual de comunicaciones escritas para la empresa. Barcelona: Graó Interactiva.

Schriver K (2017) Plain Language in the US Gains Momentum: 1940-2015. IEEE Transactions on Professional Communication 60(4): 343-383. 
Meza, Paulina; González-Catalán, Felipe; López-Ferrero, Carmen; Gutiérrez, Israel (2020). "Plain writing in the legal field: An approach from the discourse of specialists" (2020) Discourse Studies, 22(3), 356383, https://doi.org/10.1177/1461445620906027

Songa A (2013) In pursuit of clarity: how far should the drafter go? Commonwealth Law Bulletin 39(3): 415-422.

Taranilla R (2015) El género de la sentencia judicial: un análisis contrastivo del relato de hechos probados en el orden civil y en el orden penal. Ibérica 29: 63-82. 
Meza, Paulina; González-Catalán, Felipe; López-Ferrero, Carmen; Gutiérrez, Israel (2020). "Plain writing in the legal field: An approach from the discourse of specialists" (2020) Discourse Studies, 22(3), 356383, https://doi.org/10.1177/1461445620906027

ANNEX 1: Categories and macro categories

\begin{tabular}{|c|c|}
\hline Category & Macrocategory \\
\hline Plain language movement contribute to the access of legal knowledge & \multirow{4}{*}{$\begin{array}{l}\text { A: Contribution of } \\
\text { the plain language } \\
\text { movement to the } \\
\text { legal field }\end{array}$} \\
\hline $\begin{array}{l}\text { Plain language movement does not contribute to access to legal } \\
\text { knowledge }\end{array}$ & \\
\hline $\begin{array}{l}\text { Plain language movement does not contribute to the construction of legal } \\
\text { knowledge }\end{array}$ & \\
\hline $\begin{array}{l}\text { Plain language movement contributes to the construction of legal } \\
\text { knowledge }\end{array}$ & \\
\hline $\begin{array}{l}\text { Integration of actions that ensure the understanding of the legal text by any } \\
\text { citizen }\end{array}$ & \multirow{4}{*}{$\begin{array}{l}\text { B: Adaptation to the } \\
\text { communicative } \\
\text { context }\end{array}$} \\
\hline $\begin{array}{l}\text { Integration of the differences associated with the knowledge of the } \\
\text { audience or the legal field of the text }\end{array}$ & \\
\hline Clear definition of the topic and purpose of the text & \\
\hline $\begin{array}{l}\text { Complexity of the language determined by the participants of the legal } \\
\text { situation }\end{array}$ & \\
\hline Proper use of the technical language of the legal field & \multirow{8}{*}{$\begin{array}{l}\text { C: Plain writing } \\
\text { concept }\end{array}$} \\
\hline Organized expression of ideas by means of simple language & \\
\hline Absence of plain writing & \\
\hline Legal discourse has specificities that should not be ignored & \\
\hline Clear and understandable expression of ideas for the audience involved & \\
\hline Precise expression of ideas without ambiguities & \\
\hline $\begin{array}{l}\text { Use of persuasive argument, application and conclusion to convince the } \\
\text { addressee }\end{array}$ & \\
\hline Clear expression of ideas without errors associated with writing rules & \\
\hline Areas of legal communication between client and lawyer & \multirow{5}{*}{$\begin{array}{l}\text { D: Communicative } \\
\text { contexts demanding } \\
\text { plain writing }\end{array}$} \\
\hline Areas of legal communication between judge and justiciable & \\
\hline All areas of law communication & \\
\hline Areas of application of citizen language & \\
\hline $\begin{array}{l}\text { Areas of relation between lawyer and people without disciplinary } \\
\text { knowledge in the legal area }\end{array}$ & \\
\hline Complexity in the task of linking legal and common languages & \multirow{6}{*}{$\begin{array}{l}\text { E: Compatibility } \\
\text { between legal and } \\
\text { common language }\end{array}$} \\
\hline $\begin{array}{l}\text { Need by legal operators to write clearly without giving up on technical } \\
\text { accuracy }\end{array}$ & \\
\hline $\begin{array}{l}\text { Possibility of making common and legal languages compatible while } \\
\text { respecting the scientific and technical nature of the latter }\end{array}$ & \\
\hline Compatibility between common and legal languages is not necessary & \\
\hline $\begin{array}{l}\text { Linking common and legal languages determined by the situation in which } \\
\text { communication is framed }\end{array}$ & \\
\hline There is compatibility between common and legal languages & \\
\hline Plain writing to avoid ambiguities in the practicing of law & \multirow{4}{*}{$\begin{array}{l}\text { F: Purpose of plain } \\
\text { writing }\end{array}$} \\
\hline Plain writing to ensure effective access to justice for all citizens & \\
\hline Use of language to offer security in the legal field & \\
\hline Valuative writing to understand a given position & \\
\hline Use of legal technical language & \multirow{7}{*}{$\begin{array}{l}\text { G: Linguistic and } \\
\text { discursive features }\end{array}$} \\
\hline Explanations using the language often used by the addressee & \\
\hline Use of precise legal technical language & \\
\hline Application of grammar rules in the production of texts & \\
\hline Use of technical language in the legal field without simplifications & \\
\hline Application of disciplinary knowledge and information synthesis & \\
\hline Application of a logical and coherent structure in the production of & \\
\hline
\end{tabular}


Meza, Paulina; González-Catalán, Felipe; López-Ferrero, Carmen; Gutiérrez, Israel (2020). "Plain writing in the legal field: An approach from the discourse of specialists" (2020) Discourse Studies, 22(3), 356383, https://doi.org/10.1177/1461445620906027

\begin{tabular}{|c|c|}
\hline $\begin{array}{l}\text { Differences associated with the technical language used in the various } \\
\text { legal texts }\end{array}$ & \\
\hline $\begin{array}{l}\text { No differences in plain writing according to the subject, type of text or } \\
\text { information processing }\end{array}$ & \\
\hline $\begin{array}{l}\text { Differences associated with the treatment of concepts or information of the } \\
\text { legal field }\end{array}$ & \\
\hline $\begin{array}{l}\text { Differences associated with the type of discursive strategy used for the } \\
\text { treatment of an issue in the different legal texts }\end{array}$ & \\
\hline $\begin{array}{l}\text { Differences associated with the scope of law in which there are predefined } \\
\text { forms or structures }\end{array}$ & H: Variability of \\
\hline Differences associated with the requirements of each type of legal text & \\
\hline $\begin{array}{l}\text { Differences between the types of texts according to the particularities of } \\
\text { the institutions in which the production of a legal text is framed }\end{array}$ & \\
\hline $\begin{array}{l}\text { Differences associated with the formality of the text depending on the } \\
\text { context in which legal act or procedure is framed }\end{array}$ & \\
\hline $\begin{array}{l}\text { Differences associated with the reference of the facts (past or future) in the } \\
\text { various legal texts }\end{array}$ & \\
\hline
\end{tabular}

